\title{
A Review on Occupational Health in Yugoslavia
}

\author{
Marko ŠARIĆ \\ Institute for Medical Research and Occupational Health, Zagreb, Yugoslavia
}

\begin{abstract}
A review on occupational health service and activities in Yugoslavia is presented. Information on relevant legislation, organization of occupational health and worker's health care, financing, practices of occupational health units, education concerning graduate and postgraduate studies and continuous education in this field are given. Workers' morbidity pattern is also briefly discussed as well as research activities. Concluding remarks include observations on foreseeable needs and developmental orientation in occupational health in the country.
\end{abstract}

Key words: occupational health, organization, education, morbidity, research.

(Received 30 March 1987)

I have written on the subject of occupational health in Yugoslavia on several occasions (Šarić \& Vouk, 1962; Šarić, 1979). In this paper a topical review on Yugoslav occupational health is given with relevant information on legislation, organization, practice, finance, education and research. A part of the review will discuss the foreseeable needs and developmental orientation.

\section{Legislation}

Basically, workers' health care is defined by health care and health insurance laws. According to the Constitution, health protection and health care are determined by the republican (province) regulations (Yugoslavia is a federal country consisting of six socialist republics: Slovenia, Croatia, Serbia, Bosnia and Herzegovina, Montenegro, Macedonia and two autonomous provinces within Serbia-ASP Voivodina and ASP Kosovo). Therefore, occupational health care is organized by the laws and regulations at the level of republics and provinces which lay down the tasks, principles of organization and minimum requirements regarding the personnel, equipment and space of an occupational health unit. These laws also regulate the matter of workers' health insurance and a procedure for assessing temporary disability for work. Basic health insurance units are organized at a community (inter-commune) level so that the relationship between health and health insurance concerning occupational health is partly a matter of local decisions.

Occupational health activity is partly determined by regulations on safety at work, such 
as regulations on general and specific assessment of ability for work (given jointly by labour and health authorities) and regulations for jobs with an increased risk to health. Regulations on safety at work also deal with hygienic standards and control of work environment, determination and implementation of protective measures, while regulations on work relations and deal with working hours, night work, and annual leaves. A part of the regulations is subject to local decisions in industrial organizations (plants) which are entitled to take decisions in accordance with actual requirements (for example, for jobs with an increased risk to health).

Acts on disability and pension insurance which are also partly republic-(province-) based refer to disability pension, procedures for disability and residual work ability assessment and professional rehabilitation. A list of occupational diseases is determined by agreement of all republican (province) disability and pension insurance communities and is revised and amended every five years.

\section{Organization}

Workers' health care, that is, occupational health is conceived as an integral part of national health service. At local levels it is part of primary health care. From the point of view of organization, occupational health units operate within health centres (medical centres) i. e. within health institutions which also include general practice, health care for infants, school children and women, dental service, hygiene and epidemiological service (health centre) and even hospital care (medical centre). Occupational health units may be attached to industrial organizations or offer services to industry in a certain region (community). Another possibility is that an occupational health unit be instituted as an independent health organization or made part of a factory but organized as an autonomous entity.

At other levels there are occupational health departments acting within the framework of the institutes of public health (big cities, regions, republics). There are also institutes of occupational health founded either as independent organizations or linked with the university whose major tasks are specialized workers' health care and research (and education). Among these are the Institute for Medical Research and Occupational Health (founded in 1948) in Zagreb, SR Croatia and the Institute for Occupational and Radiological Protection in Belgrade, SR Serbia (founded in 1959). Centres (institutes) for safety at work exist as separate organizations.

\section{Financing}

Occupational health activities are financed by two resources: health insurance communities and industrial organizations. Basically, means for the health examination, medical care and rehabilitation are ensured by health insurance communities while manda- 
tory preventive activities (e. g. periodical health check-ups of workers at specific work places) are in the care of industrial organizations. Specific preventive programmes are financed by either resource, depending on the objectives and funds available.

Industrial organizations can ensure from their resources a standard of health protection higher than the one imposed and financed by health insurance communities. In one of the republics (SR Croatia), by law, occupational health protection as part of primary health care should be financed by industrial organizations through a direct arrangement with health service. Financial contribution of industry to the health insurance organizations in such a solution is proportionally reduced.

\section{Practices of Occupational Health Units}

The practices of occupational health units range from merely preventive activities to the programmes which are a combination of preventive and curative activities.

Dispensaries operating within health centres (medical centres) at the community level provide as a rule preventive care only. Units with a single physician perform combined programmes in which curative activities tend to prevail. In health units within large industrial organizations, health care is usually divided into preventive and curative activities. The intention is for a trained occupational health physician to be directed primarily to dealing with specific occupational health issues, that is, to preventive activities.

Preventive activities are usually carried out by one trained occupational health physician per about 5000 to 7000 workers and curative activities by one physician per 1000 to 2000 workers.

Table 1 shows the data on occupational health service in Yugoslavia. It can be seen that the number of occupational health units during the observed period of 20 years has been enlarging equally in all parts of the country. They are most numerous in industrial centres and large cities but fewer in mining areas, farming regions, forestry and in isolated construction working areas. The number of trained occupational health physicians has increased relatively more quickly compared to the number of units. Actual distribution of occupational health service in different parts of the country (republics and autonomous provinces) is shown in Table 2.

Table 1. Occupational health units and physicians in Yugoslavia (1966-1984)

\begin{tabular}{lcccc}
\hline & 1966 & 1971 & 1981 & 1984 \\
\hline Units & 804 & 1019 & 1501 & 1694 \\
Physicians (total) & 849 & 1257 & 2709 & 3306 \\
Occupational health specialists & 134 & 399 & 1016 & 1327 \\
\hline
\end{tabular}

Sources: Federal Institute of Public Health, Belgrade: Annual statistical reports on health conditions and health service in Yugoslavia. 
Table 2. Number of workers per physician in occupational health service in Yugoslav republics and autonomous provinces $(1966-1984)$

\begin{tabular}{lcccccc}
\hline & \multicolumn{5}{c}{ Number of workers per } \\
\cline { 2 - 7 } & \multicolumn{3}{c}{ physician } & \multicolumn{3}{c}{ occupational health specialist } \\
\cline { 2 - 7 } & 1966 & 1971 & 1984 & 1966 & 1971 & 1984 \\
\hline Yugoslavia (total) & 5000 & 3900 & 2100 & 31300 & 12200 & 5200 \\
Bosnia and Herzegovina & 5500 & 5500 & 1700 & 50700 & 28300 & 6000 \\
Montenegro & 7100 & 5800 & 3700 & 30700 & 27500 & 7600 \\
Croatia & 4400 & 3900 & 2100 & 30300 & 10300 & 5100 \\
Macedonia & 7900 & 4000 & 2900 & 97700 & 14700 & 8600 \\
Slovenia & 5100 & 4700 & 2700 & 26300 & 18400 & 7500 \\
Serbia outside & 3200 & 3000 & 1700 & 20500 & 8700 & 3800 \\
autonomous provinces & 4800 & 4100 & 2100 & 68700 & 11400 & 5800 \\
$\quad$ Kosovo & 5000 & 4300 & 2300 & 28800 & 19200 & 4900 \\
$\quad$ Voivodina & & & & & & \\
\hline
\end{tabular}

Sources: Federal Institute of Public Health, Belgrade: Annual statistical reports on health conditions and health service in Yugoslavia.

\section{Education}

The subject of occupational health is part of the curriculum of graduate studies of medical students with 30 to 45 hours in the 4 th or 5 th year.

There are also postgraduate studies in occupational health (two terms). The first courses of this kind were organized after the Second World War in the year 1949/50 at "Andrija Štampar" School of Public Health, Medical Faculty in Zagreb. Postgraduate courses are mandatory for specialization in occupational health which lasts 3 years and includes additional programmes in physiology of work, industrial hygiene, psychology of work, vocational medicine, mental health, rehabilitation and a part of practice within relevant clinical disciplines (occupational diseases, traumatology, cardiology, haematology, gastroenterology, dermatology, orthopedics, physical medicine and rheumatology). Those wishing to prepare a M. Sc. thesis need to attend the additional two terms (after the postgraduate course). After specialization and final examination a physician acquires the degree of occupational health specialist.

Education for nurses envisages programmes of additional occupational health training. However, this form of training has not been adequately developed yet.

The forms of continuous education of occupational health physicians and personnel have not been sufficiently elaborated although there are programmes which have been going on for a long time (industrial toxicology, radiological protection). Within occupational health education there are also specific forms (programmes) of education and training for industrial hygienists, safety engineers and industrial psychologists. 


\section{Workers' Morbidity}

In the pattern of workers' morbidity, general diseases are most prevalent with various chronic degenerative diseases on the increase. In this respect workers' morbidity in Yugoslavia does not differ essentially from the morbidity pattern in developed countries. The most frequent are respiratory diseases but their rate and share in the morbidity pattern is on the decrease. They are followed by the diseases of the locomotor apparatus, diseases of the circulatory system with arterial hypertension, as a predominant condition, whereas diseases of the digestive system are in the fourth place. On the increase are diseases related to the modern way of life (coronary heart diseases, malignant neoplasms, psychiatric diseases - in particular alcoholism and psychoneurosis). Figure 1 summarizes data for groups of diseases and their rates per 1000 workers for the years 1969 and 1980 .

A total of about 4000 occupational diseases registered in 1974 increased to 7209 in 1984. However, the daily sick-absence rate per worker for this group of diseases decreased from 46 days in 1974 to 26 in 1984. It is assumed that the number of occupational diseases exceeds the one registered officially. This is confirmed by directed investigations in certain branches of industry and some industrial organizations. Among occupational diseases the most frequent are skin diseases. Occupational hearing damages are numerous whereas occupational intoxications have been decreasing. However, pneumoconiosis is still a topical problem. According to the available data in 1984 in Yugoslavia there were 2093 cases of silicosis, silicotuberculosis and progressive massive fib-
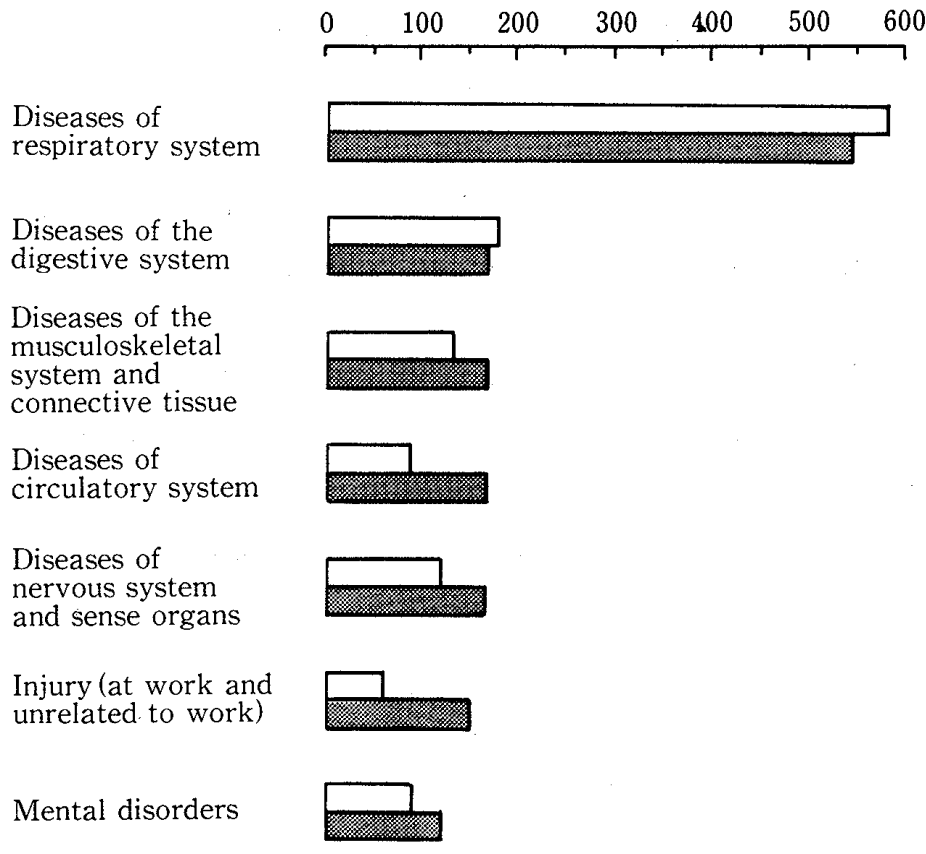

Fig. 1. Rate (per 1000) of registered diseases (groups) in Yugoslav working population (comparison: $\square$ 1969, 1980) 
rosis (coal miners) and 250 cases of asbestosis. In SR Serbia pneumoconioses stand for $3.5 \%$ of causes of disability (Vajs \& Feliks, 1985).

The rate of injuries at work (per 1000 workers) has been slightly but steadily going down (1961: 84/1000; 1971: 60/1000; 1981: 46/1000: 1984; 42/1000). The number of fatal injuries although on the decrease is still relatively high. In 1984 there were 595 fatal injuries at work, 230 in industry and mining, 106 in construction industry, 85 in traffic. This may be accounted for by relatively frequent group accidents at work.

The average daily sick-absence rate in Yugoslavia is between $4.2 \%$ and $4.6 \%$ for the period 1974-1978 whereas in 1979 it increased to $5 \%$. In the following two years the rate of daily sick-absences slightly decreased but it increased to $4.7 \%$ in 1983 and $4.8 \%$ in 1984. The causes of sick-absences in 1984 were illness $(81 \%)$, the care of a member of the family $(13.7 \%)$ and other causes $(5.7 \%)$.

According to the records of the Association of Disability and Pension Insurance Communities the number of disabled workers and disability pensioners has been increasing continuously (102/1000 of workers in 1974; 125/1000 of workers in 1984). Out of the total number of disabled workers about $3 / 4$ are invalids (without residual working ability). Among the causes of disability, cardiovascular diseases are most frequent, followed by diseases of the locomotor apparatus, mental diseases, diseases of the respiratory system and diseases of the digestive system. In the sixth place are injuries accounting for about $6 \%$ of the total causes of disability.

\section{Research}

The need for research in the field of occupational health and safety at work in accordance with industrial advancement was recognized soon after the Second World War. In 1947 in Belgrade the Serbian Academy of Sciences and Arts founded the Institute for Physiology of Work and a year later (1948) the Yugoslav Academy of Sciences and Arts founded the Institute of Industrial Hygiene in Zagreb (now: Institute for Medical Research and Occupational Health).

Investigations which were initiated and which were later given a wider institutional basis were mainly epidemiological studies on various issues concerned with pathology of work and work related diseases. A part of the research was fundamental and experimental in character. The studies dealt with toxicology of lead, mercury and other metals, toxicology of pesticides (chlorinated hydrocarbons, organophosphorus compounds and carbamates), toxicology of carbon disulphide, problems related to pneumoconioses and individual occupational pneumopathies, hearing damages, vibration injuries, decompression illness and barotrauma, damages caused by ionizing radiation, and recently effects of microwave and radio-frequency radiation, occupational skin and respiratory allergies, bronchial hyperreactivity in the production of aluminium, chronic obstructive lung disease in cement production and in coal mines, osteoarthrosis of the spine, cervicobrachial syndrome, low 
back pain related to occupation, work shift problems, etc. In most cases research was based on practical needs, and only sporadically problems were anticipated in correspondence with predicted development. A more detailed insight into the part of the investigation carried out in the field of occupational health can be obtained from the survey of the activity of the Institute for Medical Research and Occupational Health in Zagreb (Šrarić, 1985).

\section{Concluding Remarks}

When writing a review like this the author is bound to ask himself questions such as: Is the occupational health activity discussed basically well organized? Is it rational and are the results obtained in proportion with the investment?

When discussed in relation to occupational health issues in the narrow sense the organization of occupational health activity could be evaluated as being too broad. With regard to a combined health function which also includes both diagnostics and treatment of general diseases (at the level of primary health care) the activity may be said to correspond or even partly fail to meet the requirements. The combined function undoubtedly has its advantages but also has shortcomings. Certain difficulties arise particularly in large urban environments where workers live very often far from their workplaces. Occupational health services are not always evenly distributed compared to general practice which is organized according to the territorial principle, and also there is a lack of liaison between occupational health units and general practice.

Preventive activities should be more directed towards prevention of occupationally related general diseases, especially those from the group of chronic degenerative diseases (measures of primary prevention) or towards slowing down their course and delaying disability (measures of secondary and terciary prevention). Special attention should be given to work related diseases. From the point of occupational diseases and pathology of work effects of prolonged subtoxic exposure to certain pollutants including mutagenic, carcinogenic or genotoxic effects and effects of combined exposure ask for greater consideration. A significant role in this field belongs to scientific research especially to research focussing on problems of work related diseases.

One of the weaknesses of safety at work in Yugoslavia is insufficient concern for systematic improvement of environmental conditions at the work place and of cooperation between safety at work and health service.

Taking into account an ever increasing significance of psychogenic stresses in modern industry the role of an industrial psychologist becomes more and more important. Cooperation between psychology and occupational health already has its place in ergonomic approach and in search for solutions to different current problems caused partly by old but also by modern production in accordance with the ergonomic principles. 
Full advantage should be taken of the possibilities offered by the Yugoslav selfmanaging system. The workers should be better and more fully informed to be able to take interest in scientific solutions and in undertaking practical measures to promote occupational health and safety at work. This can be achieved by elaboration and implementation of adequate occupational health programmes which would reflect workers' needs and provide competent professional assessment of their goals.

\section{References}

Šarić, M. (1979): Occupational health in Yugoslavia. Proceedings, XIXth International Congress on Occupational Health, Dubrovnik 1978, Arh. Hig. Rada Toksikol., 30 (Suppl.): 1441-1445.

Šarić, M. (1985): The role of scientific research in the development of occupational health service. Ann. Ist. Super. Sanita., 21: 481-486.

Šarić, M. \& Vouk, V. B. (1962): Occupational health in Yugoslavia. Ann. Occup. Hyg., 5: 173-176. Vajs, V. \& Feliks, R. (1985): Zdravstveno stanje i zdravstvena zaštita radnika (Health condition and health protection of workers). Jugoslovenski pregled, December, pp. 473-480.

\section{ユーゴスラビアにおける労働衛生 \\ マルコ・シャリジ \\ ユーゴスラビア労衝衛生研究所}

\footnotetext{
要＼cjkstart旨： ユーゴスラビアに扔ける労衝衛生の制度および実態について紹介した。まず，関連法規， 労働衛生および健康管理の関連組織, 予算, 産業衛生機関の活動内容, この分野の卒前, 卒後教育および生涯教育について解説した。ついで，本分野における研究活動とともに労 働者の疾病構造についても簡潔に触れた。最後に, ユーゴスラビアの産業衛生分野におけ る将来の需要掞よび発展の方向性に関する意見をもって結論とした.

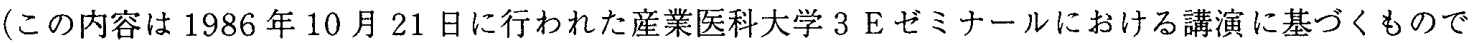
ある.)
} 